\title{
PERAN AUDITOR INTERNAL DAN SISTEM PENGENDALIAN INTERN (SPI) DALAM PENGELOLAAN RISIKO DI LEMBAGA KEUANGAN SYARIAH
}

\author{
Syahril, SE \\ Program Studi Akuntansi Syariah \\ Sekolah Tinggi Ekonomi Islam SEBI (STEI SEBI) \\ Email: abahanna80@yahoo.com
}

\begin{abstract}
ABSTRAK
Setiap kegiatan organisasi yang dilaksanakan untuk mencapai suatu tujuan atau sasaran organisasi pasti akan menghadapi berbagai risiko. Kunci keberhasilan mencapai tujuan atau sasaran organisasi adalah bagaimana pihak manajemen organisasi mengelola risiko tersebut. Terkait dengan pengelolaan risiko, implementasi audit yang bisa digunakan di lembaga keuangan syariah adalah audit internal berbasis risiko (risk based audit). Audit internal berbasis risiko merupakan pendekatan audit yang membantu manajemen dalam menilai proses pengindentifikasian risiko organisasi dan strategi antisipasi manajemen atas risiko dalam bentuk dibangunnya Sistem Pengendalian Intern (SPI) yang tepat dan memadai. Tujuan penelitian adalah untuk mengetahui sejauhmana peran auditor internal dan Sistem Pengendalian Intern (SPI) dalam pengelolaan risiko (risk management) di lembaga keuangan syariah. Pada penelitian ini penulis menggunakan metode deskriptif dengan pendekatan ORCA (Objective, Risk, Control, Action), sedangkan untuk mengidentifikasi risiko material yang dihadapi lembaga keuangan syariah, penulis menggunakan pendekatan aset (the asset approach), pendekatan lingkungan eksternal (the eksternal environment approach) dan pendekatan skenario ancaman (threat scenario approach). Secara umum dari hasil penelitian ini diketahui bahwa auditor internal dan Sistem Pengendalian Intern (SPI) mempunyai peran besar dalam proses pengelolaan risiko di lembaga keuangan syariah.
\end{abstract}

Kata Kunci: Pengelolaan Risiko, Audit Internal Berbasis Risiko, Auditor Internal, Sistem Pengendalian Intern (SPI).

\section{PENDAHULUAN}

Seperti kita ketahui bersama dalam sistem manajemen secara umum, aspek pengendalian (controlling) merupakan fungsi utama yang harus dilakukan dalam setiap pelaksanaan fungsi manajemen lainnya. Fungsi pengendalian lebih digunakan untuk melakukan koreksi guna penyempurnaan perencanaan selanjutnya. Arus globalisasi yang dipicu oleh pesatnya perkembangan teknologi informasi menjadikan manajemen suatu organisasi harus mengambil sikap dan tindakan yang cepat dan lugas dalam mengantisipasi perubahanperubahan yang mungkin terjadi, termasuk di dalamnya adalah lembaga keuangan syariah. Kegagalan pencapaian tujuan organisasi dalam sebuah lembaga keuangan syariah merupakan risiko yang harus diidentifikasi dan dihadapi. Hal ini berkaitan erat dengan kontribusi yang diberikan oleh unit 
pengawasan internal yang terdapat dalam lembaga keuangan syariah kepada pihak manajemen dalam menyikapi risiko yang dihadapi oleh manajemen dalam pencapaian tujuan organisasi. Dilain pihak, perkembangan jasa yang diberikan oleh auditor internal saat ini telah mengalami peningkatan yang luar biasa untuk merefleksikan pemberdayaan kedudukan unit pengawasan internal dalam suatu lembaga keuangan syariah. Peran auditor internal yang pada awalnya hanya bertindak sebagai pengawas semata (watchdog) dan selama ini menjadi ciri khas unit pengawasan internal telah mengalami pergeseran dan perluasan menjadi penjamin kualitas (quality assurance). The Institute of Internal Auditors (IIA) sebagai institusi profesi auditor internal dunia telah menetapkan standar profesional pelaksanaan audit internal yang menyatakan bahwa aktifitas audit internal dirancang untuk memberikan nilai tambah (value added) organisasi. Auditor internal diharapkan mempunyai peran yang cukup besar untuk membantu organisasi dalam mencapai tujuannya dengan menggunakan pendekatan yang sistematis untuk mengevaluasi dan meningkatkan efektivitas pengelolaan risiko (risk management), pengendalian (controlling) dan proses tata kelola organisasi yang baik (good corporate governance). Dalam melaksanakan proses audit di lembaga keuangan syariah, auditor internal dapat menggunakan metode audit internal berbasis risiko (risk based audit) sebagai salah satu pilihan metode audit selain audit konvensional yang selama ini dilaksanakan. Audit internal berbasis risiko merupakan pendekatan audit yang membantu manajemen dalam menilai proses pengindentifikasian risiko organisasi dan strategi antisipasi manajemen atas risiko dalam bentuk dibangunnya Sistem Pengendalian Intern (SPI) yang tepat dan memadai.

Dari latar belakang di atas, maka penulis merumuskan permasalahan yang akan dibahas dalam penelitian ini adalah : (1) Bagaimana peran auditor internal dalam pengelolaan risiko di lembaga keuangan syariah? (2) Bagaimana peran Sistem Pengendalian Intern (SPI) dalam pengelolaan risiko di lembaga keuangan syariah? (3) Bagaimana implementasi audit internal berbasis risiko dalam pengelolaan risiko di lembaga keuangan syariah?

Tujuan penelitian ini adalah : (1) Untuk mengetahui peran auditor internal dalam pengelolaan risiko di lembaga keuangan syariah. (2) Untuk mengetahui peran Sistem Pengendalian Intern (SPI) dalam pengelolaan risiko di lembaga keuangan syariah. (3) Untuk mengetahui implementasi audit internal berbasis risiko dalam pengelolaan risiko di lembaga keuangan syariah.

\section{HASIL DAN ANALISIS}

\subsection{LEMBAGA KEUANGAN SYARIAH DAN PENGELOLAAN RISIKO}

Lembaga keuangan syariah merupakan salah satu instrumen/organisasi yang didirikan untuk mengatur aturan-aturan ekonomi syariah. Sebagai bagian dari sistem ekonomi secara umum, lembaga tersebut merupakan bagian dari keseluruhan sistem sosial. Oleh karenanya, keberadaannya harus dipandang dalam konteks keseluruhan keberadaan masyarakat, serta nilai-nilai yang berlaku 
dalam masyarakat yang bersangkutan. Lembaga keuangan syariah sebagai bagian dari sistem ekonomi syariah, dalam menjalankan bisnis dan usahanya juga tidak terlepas dari saringan syariah. Oleh karena itu, lembaga keuangan syariah tidak akan mungkin membiayai usaha-usaha yang di dalamnya terkandung hal-hal yang diharamkan dan menimbulkan kemudharatan bagi masyarakat luas, serta proyek-proyek yang dapat merugikan syiar Islam. Untuk itu dalam struktur organisasi lembaga keuangan syariah harus terdapat Dewan Pengawas Syariah (DPS) yang bertugas mengawasi produk dan operasional lembaga tersebut selain auditor internal yang bertugas mengawasi tata kelola organisasi berdasarkan praktik-praktik yang baik (good corporate governance).

Pada hakikatnya setiap organisasi tentunya selalu menghadapi risiko dalam mencapai tujuannya, termasuk lembaga keuangan syariah yang tentunya juga menghadapi risiko dalam mengelola proses bisnisnya. Konsep risiko selalu memiliki keterkaitan dengan ketidakpastian atas suatu kejadian, baik yang disadari atau pun yang tidak disadari sebelumnya. Namun demikian, risiko bukanlah sesuatu yang perlu dikhawatirkan selama risiko tersebut dapat dikelola dengan baik. Pengelolaan risiko inilah yang lazim disebut dengan istilah pengelolaan risiko (risk management)

Tantangan yang dihadapi oleh pihak manajemen lembaga keuangan syariah adalah bagaimana pihak manajemen dapat mengantisipasi berbagai risiko yang memiliki peluang untuk menghambat pencapaian tujuan organisasi. Secara umum risiko yang dihadapi oleh lembaga keuangan syariah terdiri atas risiko kredit, risiko pasar dan risiko likuiditas. Oleh karena itu, untuk menumbuhkan kesadaran akan risiko di dalam suatu lembaga keuangan syariah dapat dilakukan dengan 5 (lima) hal sebagai berikut :

1. Adanya komitmen dari pimpinan puncak (top management), yakni kekuasaan dan kewibawaan pimpinan lembaga keuangan syariah sangat dibutuhkan untuk mengimplementasikan kesadaran akan risiko yang menghambat pencapaian tujuan atau target yang telah ditentukan.

2. Diajukannya pertanyaan yang tepat, yakni kondisi dimana manajemen lembaga keuangan syariah tidak selalu memiliki jawaban yang tepat, namun menjadi kewajiban mereka untuk mengajukan pertanyaan yang tepat, sepert: "apakah kita bisa mencapai hasil yang memadai sesuai dengan risiko yang kita hadapi?”, "batasan dan pengendalian apa yang kita miliki untuk meminimalisasi sistem yang tepat untuk melacak dan mengukur risiko?”, "apakah kita memiliki sumber daya manusia yang tepat dan keahlian yang efektif untuk mengelola risiko?”

3. Dikembangkannya taksonomi risiko, yakni menciptakan komunikasi yang efektif tentang persepsi yang sama atas peristilahan yang berkaitan dengan risiko. Satu hal penting dalam upaya ini adalah dengan mengembangkan taksonomi risiko, yaitu: suatu struktur yang sama yang menjelaskan kategori dan subkategori risiko, piranti, alat ukur, dan strategi pengelolaan risiko di lembaga keuangan syariah.

4. Adanya pelatihan dan pengembangan, dimana pelatihan dan pengembangan bukan saja dapat membantu membangun kesadaran akan 
risiko, tetapi juga dapat melengkapi pegawai dengan keahlian dan piranti yang mereka butuhkan untuk mengelola risiko di lembaga keuangan syariah.

5. Dikaitkannya kompensasi dengan risiko, dimana kesadaran akan risiko dapat dikembangkan dengan menanamkan kesadaran bahwa pengelolaan risiko merupakan bagian dari tugas pegawai sehari-hari, dan bahwa kompensasi insentif mereka dikaitkan dengan kinerja risiko dan bisnis.

\subsection{PERAN AUDITOR INTERNAL DALAM PENGELOLAAN RISIKO}

Peran auditor internal berkembang sejalan dengan tantangan organisasi dan perubahan paradigma auditor internal itu sendiri. Paradigma lama yang menempatkan auditor internal berperan sebagai pengawas semata (watchdog) berubah menjadi peran sebagai konsultan (consultant) dan katalis (catalyst) atau penjamin kualitas (quality assurance). Perubahan paradigma ini tidak berarti bahwa peran sebagai watchdog dilupakan, tetapi justru peran auditor internal semakin diperluas dan dibutuhkan dalam proses tata kelola organisasi di lembaga keuangan syariah. Tabel berikut ini menggambarkan secara singkat perubahan paradigma auditor internal dalam pengelolaan risiko.

Tabel 2.1 Perubahan Paradigma Auditor Internal

\begin{tabular}{|c|l|l|l|l|}
\hline No & Uraian & \multicolumn{1}{|c|}{ Watchdog } & \multicolumn{1}{|c|}{ Consultant } & \multicolumn{1}{|c|}{ Catalyst } \\
\hline 1. & Proses & Audit Kepatuhan & Audit Operasional & Audit Berbasis Risiko \\
\hline 2. & Fokus & Penyimpangan & Alokasi Sumber Daya & Nilai (value) \\
\hline 3. & Dampak & Jangka Pendek & Jangka Menengah & Jangka Panjang \\
\hline
\end{tabular}

Sumber : Audittindo

Peran auditor internal sebagai pengawas semata (watchdog) meliputi aktivitas inspeksi, observasi, perhitungan, pengujian transaksi yang bertujuan untuk memastikan ketaatan proses bisnis lembaga keuangan syariah terhadap ketentuan, peraturan atau kebijakan yang telah ditetapkan. Metode audit yang dipilih adalah audit kepatuhan (compliance audit) dan apabila ditemukan penyimpangan dapat dilakukan koreksi atas Sistem Pengendalian Intern (SPI). Peran watchdog umumnya menghasilkan rekomendasi yang mempunyai dampak jangka pendek yakni perbaikan atas kesalahan yang sudah terjadi. Peran auditor internal sebagai konsultan (consultant) diharapkan dapat memberikan manfaat berupa nasehat (advice) dalam pengelolaan alokasi sumber daya (resources) di lembaga keuangan syariah sehingga dapat membantu pihak manajemen lembaga keuangan syariah. Metode audit yang dipilih adalah audit operasional (operational audit) yakni untuk meyakinkan apakah organisasi telah memanfaatkan sumber daya organisasi secara ekonomis, efisien, dan efektif sehingga dapat dinilai apakah manajemen lembaga keuangan syariah telah menjalankan aktivitas organisasi yang mengarah kepada sasaran dan tujuan organisasi. Rekomendasi yang dihasilkan umumnya bersifat jangkah menengah. Peran auditor sebagai katalis (catalyst) berkaitan dengan fungsi auditor sebagai penjamin qualitas (quality assurance). Auditor internal diharapkan dapat membimbing manajemen lembaga keuangan syariah dalam proses pengelolan 
risiko (risk management). Peran sebagai penjamin kualitas bertujuan untuk meyakinkan bahwa aktivitas organisasi telah menghasilkan keluaran (output) yang dapat memenuhi kebutuhan penggunanya. Dalam menjalankan perannya sebagai katalis, auditor internal berperan sebagai fasilitator dan agen perubahan (agent of change). Dampak dari peran ini bersifat jangka panjang karena fokus katalis adalah nilai jangka panjang (long-term values) dari lembaga keuangan syariah, terutama berkaitan dengan tujuan organisasi yang dapat memenuhi kepuasan pelanggan (customer satisfaction) dan masyarakat (stakeholders). Hubungan antara pengelolaan risiko organisasi (enterprise risk management) lembaga keuangan syariah dengan peran auditor internal dalam pengelolaan risiko adalah menyediakan kerangka kerja bagi auditor internal untuk lebih memahami risiko yang dihadapi oleh manajemen lembaga keuangan syariah, baik secara individu maupun organisasi secara keseluruhan. Pemahaman potensi risiko akan memudahkan auditor internal memfokuskan sumber daya yang tersedia pada area atau bidang yang memiliki risiko paling tinggi dan kemudian mengembangkan prosedur audit untuk mereviu, menguji, dan mengevaluasi pengendalian pada bidang yang memiliki risiko yang paling tinggi.

Auditor internal dapat mengembangkan proses audit yang berganda (multiple steps process audit) berdasarkan kerangka pengelolaan risiko organisasi lembaga keuangan syariah melalui 4 (empat) tahapan sebagai berikut:

1. Mendefinisikan proses yang mencakup kegiatan organisasi;

2. Mengurutkan dan memberikan skor atas proses kegiatan berdasarkan risikonya masing-masing;

3. Menilai proses kegiatan yang berisiko dengan penekanan pada bidang yang mengandung risiko yang lebih tinggi;

4. Mengusulkan tindakan perancangan pengendalian atas proses kegiatan yang berisiko tinggi.

\subsection{PERAN SISTEM PENGENDALIAN INTERN (SPI) DALAM PENGELOLAAN RISIKO}

Dalam teori akuntansi dan organisasi, Sistem Pengendalian Intern (intern control system) didefinisikan sebagai suatu proses, yang dipengaruhi oleh sumber daya manusia dan sistem teknologi informasi, yang dirancang untuk membantu organisasi mencapai suatu tujuan atau objektif tertentu. Sistem Pengendalian intern (SPI) merupakan suatu cara untuk mengarahkan, mengawasi, dan mengukur sumber daya suatu organisasi. SPI berperan penting untuk mencegah dan mendeteksi penggelapan (fraud) dan melindungi sumber daya lembaga keuangan syariah baik yang berwujud (seperti mesin) maupun yang tidak berwujud (seperti merek perusahaan). Pada tingkatan organisasi lembaga keuangan syariah, tujuan SPI berkaitan erat dengan keandalan laporan keuangan, umpan balik yang tepat waktu terhadap pencapaian tujuan-tujuan operasional dan strategis, serta kepatuhan pada hukum dan regulasi. Pada tingkatan transaksi spesifik, SPI merujuk pada aksi yang dilakukan untuk mencapai suatu tujuan tertentu. Prosedur SPI mengurangi variasi proses dan pada gilirannya 
memberikan hasil yang lebih dapat diperkirakan. Tujuan SPI adalah menjamin manajemen lembaga keuangan syariah agar :

1. Tujuan yang telah ditetapkan di lembaga keuangan syariah akan dapat dicapai;

2. Laporan keuangan yang dihasilkan lembaga keuangan syariah dapat dipercaya;

3. Kegiatan lembaga keuangan syariah sejalan dengan hukum dan peraturan yang berlaku.

SPI juga dapat mencegah kerugian atau pemborosan pengolahan sumber daya lembaga keuangan syariah. SPI dapat menyediakan informasi tentang bagaimana menilai kinerja lembaga keuangan syariah serta menyediakan informasi yang akan digunakan sebagai pedoman dalam perencanaan dimasa depan. Menurut COSO (Commitee of Sponsoring Organizations of The Treadway Commission), SPI dapat diklasifikasikan menjadi 5 (lima) elemen yang meliputi: Lingkungan Pengendalian (Control Environment), Penilaian Risiko (Risk Assesment), Aktivitas Pengendalian (Control Activities), Informasi dan Komunikasi (Information and Communication), serta Pemantauan (Monitoring).

1. Lingkungan Pengendalian (Control Environment), lingkungan pengendalian di lembaga keuangan syariah mencakup hal-hal sebagai berikut:

a. Penegakan integritas dan etika;

b. Komitmen terhadap kompetensi;

c. Kepemimpinan yang kondusif;

d. Struktur organisasi yang sesuai kebutuhan;

e. Pendelegasian wewenang dan tanggung jawab yang tepat;

f. Kebijakan yang sehat tentang pembinaan SDM;

g. Peran auditor internal yang efektif;

h. Hubungan kerja yang harmonis.

Lingkungan pengendalian ini amat penting karena menjadi dasar keefektifan unsur-unsur pengendalian intern yang lain.

2. Penilaian Risiko (Risk Assesment), penilaian risiko di lembaga keuangan syariah mencakup hal-hal sebagai berikut:

a. Identifikasi risiko;

b. Analisis risiko.

Karena pada hakikatnya semua organisasi memiliki risiko termasuk lembaga keuangan syariah. Dalam kondisi apapun yang namanya risiko pasti ada dalam suatu aktivitas, baik aktivitas yang berkaitan dengan bisnis maupun non bisnis. Suatu risiko yang telah di identifikasi dapat di analisis dan evaluasi sehingga dapat di perkirakan intensitas dan tindakan yang dapat meminimalkannya. Penilaian risiko adalah rangkaian kegiatan mengenali, mengukur dan memprioritaskan risiko. Untuk dapat menilai risiko, langkahlangkah yang harus dilakukan antara lain :

a. Mengestimasi tingkat signifikansi dari risiko;

b. Mengukur tingkat kemungkinan terjadinya risiko; 
c. Mempertimbangkan bagaimana risiko dikelola.

3. Aktivitas Pengendalian (Control Activities), aktivitas pengendalian ditetapkan untuk menstandarisasi proses kerja sehingga menjamin tercapainya tujuan lembaga keuangan syariah dan mencegah atau mendeteksi terjadinya penyimpangan. Aktivitas pengendalian di lembaga keuangan syariah mencakup hal-hal sebagai berikut:

a. Reviu atas kinerja lembaga;

b. Pembinaan SDM;

c. Pengendalian pengelolaan sistem informasi;

d. Pengendalian fisik atas aset;

e. Penetapan reviu indikator dan ukuran kinerja;

f. Pemisahan fungsi;

g. Otorisasi transaksi dan kejadian penting;

h. Pencatatan yang akurat dan tepat waktu;

i. Pembatasan akses atas sumber daya;

j. Akuntabilitas terhadap sumber daya;

k. Dokumentasi atas SPI.

4. Informasi dan Komunikasi (Information and Communication), informasi dan komunikasi merupakan elemen yang penting dari SPI. Informasi tentang lingkungan pengendalian, penilaian risiko, dan aktivitas pengendalian diperlukan oleh manajemen lembaga keuangan syariah sebagai pedoman operasional dan menjamin ketaatan dengan pelaporan hukum dan peraturanperaturan yang berlaku pada lembaga keuangan syariah. Informasi dan komunikasi di lembaga keuangan syariah meliputi:

a. Sarana komunikasi;

b. Manajemen sistem informasi.

5. Pemantauan (Monitoring), proses pemantauan terhadap SPI akan menemukan kekurangan serta meningkatkan efektivitas pengendalian. Pemantauan di lembaga keuangan syariah meliputi:

a. Monitoring berkelanjutan;

b. Evaluasi terpisah;

c. Tindak lanjut hasil monitoring.

Pada intinya, Sistem Pengendalian Intern (SPI) yang terdiri atas 5 (lima) elemen penting didalamnya berperan penting dalam pengelolaan risiko di lembaga keuangan syariah untuk mencegah dan mendeteksi terjadinya penyimpangan dan melindungi sumber daya yang dimiliki oleh lembaga keuangan syariah. Peran SPI dalam pengelolaan risiko di lembaga keuangan syariah dapat bersifat soft control (seperti integritas dan etika) atau bersifat hard control (seperti SOP).

Dari pembahasan di atas, diketahui bahwa peran auditor internal dan Sistem Pengendalian Intern (SPI) mempunyai peran yang sangat besar dalam proses pengelolaan risiko (risk management) di lembaga keuangan syariah, dimana peran auditor internal sebagai katalis akan membantu manajemen lembaga keuangan syariah dalam pengelolaan risiko dan pencapaian tujuan organisasi, sedangkan peran SPI dengan kelima unsurnya akan membantu manajemen 
lembaga keuangan syariah baik yang bersifat soft control maupun yang bersifat hard control yang pada akhirnya akan menghasilkan kolaborasi luar biasa dalam menciptakan tata kelola organisasi yang baik (good corporate governance) di lembaga keuangan syariah.

2.4 IMPLEMENTASI AUDIT INTERNAL BERBASIS RISIKO DALAM PENGELOLAAN RISIKO

Selain meneliti peran auditor internal dan SPI dalam pengelolaan risiko di lembaga keuangan syariah, penulis dalam penelitian ini juga telah memilih metode audit internal berbasis risiko (risk based audit) dalam proses pengelolaan risiko dilembaga keuangan syariah, karena metode ini mempunyai kaitan erat dengan peran auditor internal sebagai katalis. Audit internal berbasis risiko merupakan metode audit yang membantu manajemen lembaga keuangan syariah dalam menilai proses pengidentifikasian risiko dan strategi antisipasi yang harus dilakukan manajemen lembaga keuangan syariah atas risiko yang dihadapi dalam bentuk dibangunnya Sistem Pengendalian Intern (SPI) yang tepat dan memadai.

Melalui audit internal berbasis risiko, auditor internal dapat berpartisipasi dalam memberikan kontribusinya atas tercapainya tujuan organisasi. Perencanaan audit internal berbasis risiko dimulai dari pengidentifikasian unit atau objek yang berpotensi untuk diaudit (audit universe), diikuti dengan pemilihan dan penetapan unit yang akan diaudit (auditable units). Untuk setiap unit individu yang ditetapkan untuk diaudit dilakukan pendekatan risiko sebagai dasar pengalokasian sumber daya yang tersedia. Sedangkan metode pengelolaan risiko yang dipilih dalam penerapan audit adalah metode ORCA (Objective, Risk, Control, Action).

Adapun tahapan dalam menggunakan Metode ORCA terdiri atas 5 (lima) tahapan yang diuraikan sebagai berikut:

1. Tahapan pertama adalah Identify Business Objectives yaitu dimulai dari pengidentifikasian tujuan organisasi lembaga keuangan syariah;

2. Tahapan kedua adalah Analyze Risk Exposures yakni usaha menganalisis hal-hal apa saja yang dapat menggagalkan atau setidaknya menghalangi tujuan organisasi lembaga keuangan syariah yang telah ditetapkan;

3. Tahapan ketiga adalah Control in Place yaitu pengupayaan mitigasi atas risiko yang dikategorikan tinggi dalam bentuk dibangunnya suatu Sistem Pengendalian Intern (SPI) yang memadai;

4. Tahapan keempat adalah Develop and Implement Action Plans yakni mengembangkan dan mengimplementasikan rencana tindakan perbaikan yang diperlukan untuk memperkuat pengendalian atas risiko yang berpotensi besar akan terjadi;

5. Tahapan kelima adalah Monitor Results yaitu pemantauan atas proses kerja. Dalam proses pemantauan ini perbaikan secara terus menerus selalu dilakukan untuk mengantisipasi risiko yang menghalangi pencapaian tujuan organisasi. 


\subsection{PENDEKATAN IDENTIFIKASI RISIKO DALAM PENGELOLAAN RISIKO}

Selain menggunakan metode ORCA dalam menunjang audit internal berbasis risiko di lembaga keuangan syariah, penulis juga menggunakan 3 (tiga) pendekatan identifikasi risiko yang terdiri atas :

1. Pendekatan Aset (the asset approach), pendekatan aset disebut juga dengan analisis kerentanan (exposure analysis) yaitu pendekatan pengidentifikasian risiko dari perspektif ukuran aset, jenis aset, dan lokasi aset. Pertanyaan utama dari penggunaan pendekatan ini adalah: “apa yang dapat menyebabkan hilang atau rusaknya suatu aset?”. Analisis kerentanan ini berfokus kepada risiko yang melekat pada aset organisasi lembaga keuangan syariah, seperti: kehilangan, kerusakan, keusangan, penggunaan aset di bawah kapasitas normal, serta risiko ketidakpuasan pegawai.

2. Pendekatan Lingkungan Eksternal (the eksternal environment approach), pendekatan lingkungan eksternal disebut juga dengan analisis lingkungan (environmental analysis) yaitu pendekatan pengidentifikasian risiko dari perspektif adanya perubahan potensial dari lingkungan eksternal. Analisis lingkungan eksternal berfokus kepada perubahan lingkungan eksternal yang berpengaruh terhadap proses dan pengendalian manajemen lembaga keuangan syariah, seperti: kondisi ekonomi, perubahan peraturan pemerintah, pesaing, mitra usaha, pelanggan, serikat pekerja, dan teknologi. Pertanyaan yang dapat diajukan dalam penggunaan pendekatan ini adalah: “apa konsekuensinya bagi organisasi dengan adanya perubahan lingkungan?”

3. Pendekatan Skenario Ancaman (threat scenario approach), yakni pendekatan pengidentifikasian risiko dengan menggunakan skenario narasi terhadap ancaman tertentu seperti: bencana alam atau kecurangan. Pendekatan ini adalah analisis terhadap kemungkinan yang dapat mengurangi dan menghambat efektivitas Sistem Pengendalian Intern (SPI), termasuk kemungkinan timbulnya praktik kecurangan (fraud), Korupsi, Kolusi dan Nepotisme (KKN), serta bencana alam. Pendekatan ini berguna untuk mengeksplorasi kelemahan sistematis atas kejadian yang memiliki probabilitas rendah atau konsekuensi tinggi seperti: adanya bencana dan kejadian non-statistikal seperti kecurangan yang diniati.

Dari ketiga pendekatan analisis risiko di atas memiliki satu orientasi yang sama, yakni mengidentifikasi “what could go wrong” dari lembaga keuangan syariah. Pemberian penilaian atas faktor risiko dapat dilakukan dengan menggunakan pemberian skoring, misalnya menggunakan skoring 1-5 dengan kriteria sebagai berikut:

Angka 5 = Pengaruhnya sangat besar

Angka 4 = Pengaruhnya besar

Angka 3 = Pengaruhnya sedang

Angka 2 = Pengaruhnya kecil

Angka 1 = Pengaruhnya sangat kecil 


\subsection{TAHAPAN PROSES PENGELOLAAN RISIKO}

Setelah pihak manajemen lembaga keuangan syariah menentukan jenis risiko, penilaian risiko dan identifikasi risiko yang dihadapi, maka manajemen dapat melakukan proses pengelolaan risiko yang dilustrasikan pada gambar dibawah ini:

Gambar 2.1 Tahapan Pengelolaan Risiko

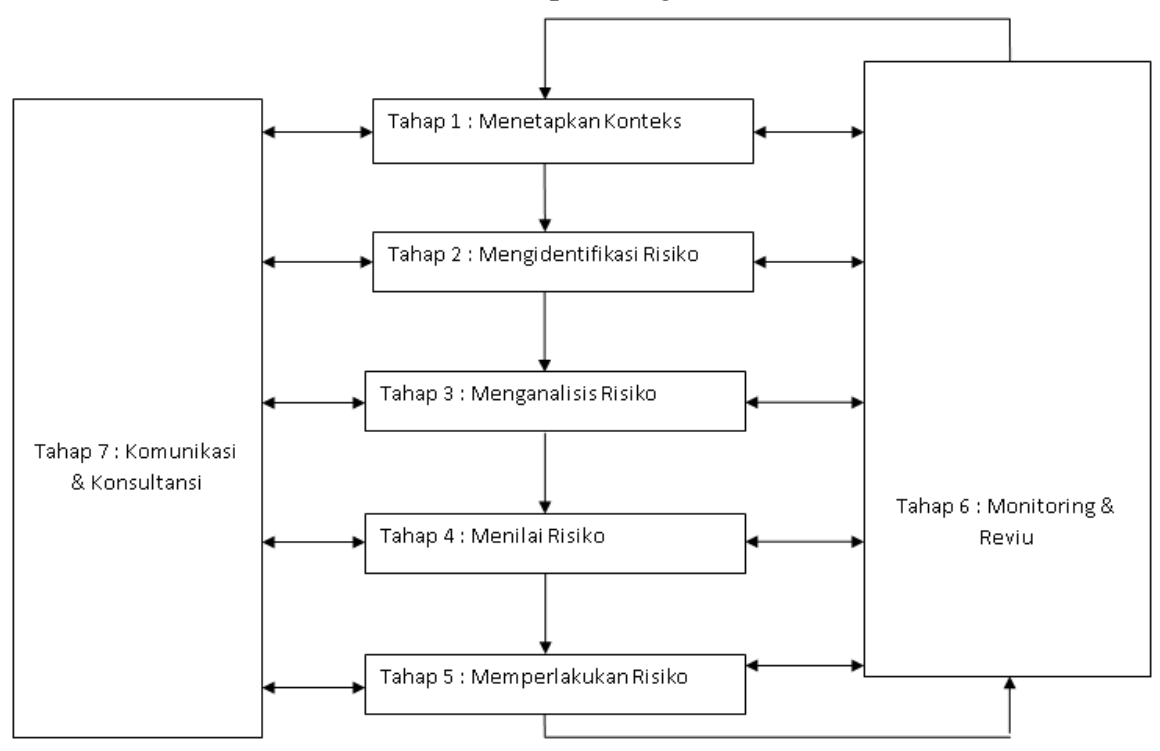

Sumber: Audittindo

Adapun tahapan pengelolaan risiko di lembaga keuangan syariah dapat diuraikan sebagai berikut:

1. Tahap 1: Menetapkan Konteks, identifikasi risiko seringkali dianggap sebagai tahapan utama dalam proses pengelolaan risiko di lembaga keuangan syariah, namun seperti terlihat dalam gambar di atas bahwa untuk dapat mengenali risiko terlebih dahulu harus diperoleh pemahaman mengenai "what is at risk". Untuk memastikan bahwa semua risiko signifikan sudah terekam maka harus dipahami dengan baik tujuan organisasi dimana risiko dikelola.

2. Tahap 2: Mengidentifikasi Risiko, merupakan tahapan yang sangat kritikal dalam proses pengelolaan risiko yakni merekam semua risiko yang dihadapi lembaga keuangan syariah baik yang sudah maupun yang belum dikendalikan melalui Sistem Pengendalian Intern (SPI).

3. Tahap 3: Menganalisis Risiko, merupakan tahapan untuk memisahkan risiko minor dan risiko mayor serta mengidentifikasi Sistem Pengendalian Intern (SPI) yang dimiliki lembaga keuangan syariah serta menentukan konsekuensi dan likelihood (kecenderungan) risiko lembaga keuangan syariah. Sumber data dan informasi yang digunakan untuk menentukan konsekuensi dan 
likelihood adalah catatan masa lalu, justifikasi berdasarkan pengalaman yang relevan, literatur, riset pasar, pengujian dan prototype, model ekonomi, pertimbangan ahli dan spesialis.

4. Tahap 4: Menilai Risiko, merupakan tahapan untuk membandingkan tingkat risiko dengan kriteria risiko pada basis yang sama. Hasil penilaian risiko adalah berupa daftar prioritas risiko dimana area yang dinilai berisiko tinggi ditindaklanjuti dengan menerapkan audit internal berbasis risiko dan yang berisiko rendah dipantau secara berkala.

5. Tahap 5: Memperlakukan Risiko, dalam tahapan perlakuan risiko dapat ditempuh dengan jalan:

a. Mengidentifikasi opsi perlakuan risiko, dengan opsi: menghindari risiko, mengalihkan risiko, mentoleransi risiko dengan suatu rencana kontinjen, mentoleransi risiko tanpa suatu rencana kontinjen, mengurangi likelihood risiko.

b. Menilai opsi perlakuan risiko, didasarkan pada luas pengurangan risiko dan besarnya manfaat/kesempatan yang tercipta.

c. Mempersiapkan rencana perlakuan risiko, yakni dengan menentukan penanggungjawab, jadwal, outcome yang diharapkan, anggaran, ukuran kinerja dan penelahaan.

d. Implementasi rencana perlakuan risiko, yakni mempertimbangkan apabila masih terdapat risiko residual (sisa), maka harus diputuskan apakah akan menahan risiko atau mengulangi proses perlakuan risiko.

6. Tahap 6: Monitoring dan Reviu, pada tahapan ini monitoring dan reviu Sistem Pengendalian Internal (SPI) dilakukan untuk meyakinkan apakah perubahan kondisi lingkungan tidak mengubah prioritas dan apakah rencana manajemen lembaga keuangan syariah tetap relevan dengan perubahan yang terjadi.

7. Tahap 7: Komunikasi dan Konsultansi, pada tahapan ini dilakukan komunikasi mengenai risiko dan cara mengelolanya kepada setiap stakeholder dan harus dilakukan pada setiap pengelolaan risiko di lembaga keuangan syariah.

\section{SIMPULAN}

\subsection{KESIMPULAN PENELITIAN}

Berdasarkan hasil analisis dan pembahasan yang telah dikemukakan sebelumnya dan kemudian dikaitkan dengan perumusan masalah dan tujuan penelitian ini, maka dapat diambil kesimpulan sebagai berikut: (1) Dari hasil penelitian menggunakan analisis deskriptif diketahui bahwa auditor internal mempunyai peran yang cukup besar dalam pengelolaan risiko di lembaga keuangan syariah terutama jika auditor internal sudah dapat berperan sebagai katalis atau penjamin kualitas (quality assurance). (2) diketahui bahwa Sistem Pengendalian Intern (SPI) juga mempunyai peran yang cukup besar dalam pengelolaan risiko di lembaga keuangan syariah baik yang bersifat soft control maupun yang bersifat 
hard control. (3) diketahui bahwa implementasi audit internal berbasis risiko ternyata menunjang proses pengelolaan risiko di lembaga keuangan syariah dengan jalan memfokuskan audit pada risiko paling tinggi yang dihadapi lembaga keuangan syariah.

\subsection{SARAN PENELITIAN}

Berdasarkan hasil analisis dan kesimpulan penelitian, maka dapat di buat saran sebagai berikut: (1) Perlu dilakukan penelitian lanjutan tentang kaitan antara pengelolaan risiko di lembaga keuangan syariah dengan variabel-variabel lain yang belum tercover dalam penelitian ini. (2) Perlu adanya sinergi yang efektif antara Dewan Pengawas Syariah (DPS) sebagai pengawas produk yang dihasilkan lembaga keuangan syariah dengan Auditor Internal sebagai penjamin kualitas (quality assurance) sehingga lembaga keuangan syariah tidak hanya berfokus pada laba semata (profit oriented), tetapi juga berfokus pada kemaslahatan umat (falah oriented) demi terwujudnya tata kelola organisasi lembaga keuangan syariah yang baik (good corporate governance).

\section{DAFTAR PUSTAKA}

Antonio, M.Syafi'i, 2001; Bank Syariah dari Teori ke Praktik, Gema Insani Press, Jakarta.

Audittindo Education, 2006; An Introductory Course for Implementing RiskBased Auditing, Indeks, Jakarta.

Dunil, Z, 2005; Bank Auditing - Risk Based Auditing, Indeks, Jakarta.

Kountur, Ronny, 2007; Metode Penelitian Untuk Penulisan Skripsi dan Tesis Edisi 2, Penerbit PPM, Jakarta.

Merna, T and Al-Thani, Faisal F, 2005; Corporate Risk Management - An Organizational Perspective, John Wiley and Sons, Ltd.

Pickett, K.H. Spencer, 2003; The Internal Auditing Handbook, John Wiley and Sons, Ltd.

Muhammad, 2007; Lembaga Ekonomi Syariah, Graha Ilmu, Yogyakarta.

Saladin, Djaslim dan Absus Salam DZ, 2000; Konsep Dasar Ekonomi dan Lembaga Keuangan, Linda Karya, Bandung.

Subiyanto, Ibnu, 1993; Metodologi Penelitian, Penerbit Gunadarma, Jakarta.

Sudarsono, Heri, 2003; Bank dan Lembaga Keuangan Syariah, Ekonisia, Yogyakarta. 
Sugiyono, 2005; Metode Penelitian Bisnis, CV Alfabeta, Bandung.

Tampubolon, Robert, 2005; Risk and Systems Based Internal Auditing, Elex Media Komputindo, Jakarta. 